Syntax Literate : Jurnal Ilmiah Indonesia p-ISSN: 2541-0849

e-ISSN : 2548-1398

Vol. 5, No. 1 Januari 2020

\title{
KUALITAS PELAYANAN ANGKUTAN UMUM TRANS SARBAGITA KORIDOR I (KOTA-GWK) TAHUN 2018
}

\section{Bhakti Nur Avianto dan Rhena Dindayanti}

Fakultas Ilmu Sosial dan Ilmu Politik Universitas Nasional

Email: bhakti.nur.avianto@civitas.unas.ac.id dan rhena.dinda@gmail.com

\begin{abstract}
Abstrak
Penelitian ini dilatarbelakangi belum optimalnya pengoperasian transportasi angkutan umum bus di Tahun 2018 yang dikelola Trans Sarbagita dibawah kewenangan Dinas Perhubungan, Informasi dan Komunikasi Provinsi Bali. Masalah tersebut ditunjukkan dari rendahnya kepuasan pengguna bus yang diobservasi dari penyediaan sarana halte bus tidak representatif, keterlambatan jarak kedatangan antara bus yang satu dengan yang lainnya, tidak memiliki jalur sendiri sehingga menimbulkan kemacaten dan antrian cukup padat, selain itu hanya menjangkau wilayah tertentu dikarenakan pengurangan armada. Penelitian ini menggunakan pendekatan kualitatif deskriptif untuk menganalisis dengan temuan data dan fakta yang terjadi selama penelitian berlangsung. Hasil penelitian ini menunjukkan bahwa kualitas pelayanan angkutan umum Trans Sarbagita Koridor I (Kota-Graha Wisnu Kencana) memiliki kecenderungan belum memuaskan pengguna layanan bus yang dilihat ketampakan fisik, kehandalan, ketanggapan, jaminan, dan empati. Sehingga Dinas Perhubungan, Informasi dan Komunikasi Provinsi Bali segera melakukan rehabilitasi atau fasilitas publik yang mengalami penurunan kualitas baik karena faktor kelalaian individu atau alamiah. Seperti, papan tulisan berjalan yang tidak beroperasi atau mati, vandalism halte, pemisahan koridor separator jalan bus, serta penambahan rute ke jalur wisata ekslusif.
\end{abstract}

Kata kunci: Transportasi, kualitas pelayanan, kepuasan pengguna.

\section{Pendahuluan}

Transportasi merupakan unsur vital dalam kehidupan bangsa dan dalam memupuk kesatuan dan persatuan bangsa. Pembangunan di bidang transportasi sebagai pendukung pembangunan sektor lainnya dalam mewujudkan sasaran pembangunan nasional di seluruh wilayah baik di perkotaan maupun di perdesaan. Pentingnya sistem transportasi tercermin dengan semakin meningkatnya kebutuhan jasa angkutan bagi mobilitas masyarakat maupun barang di dalam negeri dan luar negeri serta berperan sebagai pendorong dan penggerak bagi pertumbuhan daerah dan pengembangan wilayah. Menyadari pentingnya posisi dan peranan sistem transportasi harus ditata dalam satu kesatuan sistem transportasi nasional secara terpadu dan mampu mewujudkan penyediaan jasa transportasi yang seimbang dengan tingkat kebutuhan, keselamatan, keamanan, keefektifan dan keefisienan. Dengan dikembangkannya transportasi maka 
terjadi pemerataan pembangunan di seluruh wilayah dimana hal itu dapat memberi dampak pada kesejahteraan masyarakat. Maka dari itu, pembangunan transportasi diarahkan untuk meningkatkan pelayanan jasa transportasi secara efisien, handal, berkualitas, aman, dan terjangkau.

Pada tanggal 18 Agustus 2011 adalah langkah awal peluncuran pelaksanaan moda Trans Sarbagita dengan membuka Koridor II (Batubulan-Nusadua) dari 17 koridor yang direncanakan. Didahulukannya Koridor II ini karena ketersediaan bus yang merupakan hibah dari Kementerian Perhubungan. Bus sebanyak 15 unit ini merupakan bus berkapasitas besar sehingga dialokasikan untuk Koridor II (Batubulan-Nusadua) karena jalan lebih lebar. Selanjutnya diluncurkan Koridor I (Kota-GWK) setelah 10 bus sedang yang merupakan hibah dari Kementerian Perhubungan tiba. Trans Sarbagita memiliki road map pengembangan yang cukup panjang karena kondisi transportasi khususnya lalu lintas yang belum terbiasa menggunakan angkutan umum. Pada 2011-2013 adalah tahun untuk pengenalan layanan, membangun citra, dan sosialisasi lanjutan serta evaluasi, 2014-2019 memantapkan dan mengembangkan layanan, dan 2019 seterusnya transportasi publik diharapkan menjadi pilihan moda transportasi utama masyarakat Sarbagita (akronim dari Denpasar-Badung-Gianyar-Tabanan) adalah sebuah kawasan metropolitan di Provinsi Bali yang terdiri dari Kota Denpasar, Kabupaten Badung, Kabupaten Gianyar dan Kabupaten Tabanan. Kawasan Perkotaan ini dibentuk berdasarkan Peraturan Presiden Nomor 45 Tahun 2011, yang selanjutnya diubah dengan Peraturan Presiden Nomor 51 Tahun 2014.

Pada awal peluncurannya Trans Sarbagita ini tidak dikenakan tarif sebagai strategi untuk memikat para calon penumpang. Namun sejak Januari 2013 dikenakan tarif Rp 3.500 untuk penumpang umum dan Rp 2.500 untuk pelajar dan mahasiswa dengan menggunakan seragam maupun menunjukkan kartu tanda pelajar. Waktu pelayanan setiap hari mulai pukul 05.00-21.00 WITA dengan jarak keberangkatan antar bus setiap 15 menit. Namun setelah 7 Tahun beroperasi di Bali, angkutan Trans Sarbagita bukan kian berkembang melainkan semakin terpuruk.

Banyaknya masalah-masalah yang terjadi seperti lambatnya pembangunan 17 koridor dimana sampai saat ini hanya 2 (Dua) koridor saja yang beroperasi, tidak adanya bus pengumpan (feeder) yang dapat mengantarkan penumpang dari halte-halte Trans Sarbagita yang rata-rata berada di jalan protokol, waktu kedatangan yang menjadi 1 jam sekali bahkan lebih. Sedangkan untuk biaya operasional yang dianggarkan Pemerintah Provinsi Bali juga mengalami penurunan.

Pada tahun 2018 hanya berjumlah Rp 4 miliar, yang pada tahun 2017 masih berjumlah Rp 13 miliar. Kemudian per 1 Januari 2018, jumlah Bus Trans Sarbagita dikurangi dari 25 bus menjadi 10 bus berkapasitas 35 penumpang, di mana 10 bus tersebut dibagi ke dua koridor yang beroperasi. Karena beberapa masalah tersebut, Trans Sarbagita ini mengalami penurunan jumlah penumpang khususnya di akhir Tahun 2018 sebesar 45,47\%, sebagaimana terlihat dalam tabel berikut: 
Tabel 1 jumlah penumpang Trans Sarbagita Tahun 2013-2018

\begin{tabular}{|c|c|c|c|c|c|}
\hline \multirow{2}{*}{ Tahun } & \multicolumn{2}{|c|}{ Koridor I Kota - GWK } & \multirow{2}{*}{$\begin{array}{l}\text { Target } \\
\text { (Kursi } \\
30.000 / \\
\text { bulan) }\end{array}$} & \multirow{2}{*}{ Realisasi } & \multirow{2}{*}{$\begin{array}{c}\begin{array}{c}\text { Rasio } \\
\text { Efektif }\end{array} \\
(\%)\end{array}$} \\
\hline & $\begin{array}{l}\text { Sekali } \\
\text { Pakai } \\
\text { Umum }\end{array}$ & $\begin{array}{l}\text { Sekali } \\
\text { Pakai } \\
\text { Pelajar }\end{array}$ & & & \\
\hline 2013 & 162.696 & 145.531 & 360.000 & 308.227 & 85,62 \\
\hline 2014 & 157.259 & 166.144 & 360.000 & 323.403 & 89,83 \\
\hline 2015 & 140.873 & 144.462 & 360.000 & 285.335 & 79,26 \\
\hline 2016 & 156.588 & 158.325 & 360.000 & 314.913 & 87,48 \\
\hline 2017 & 126.898 & 147.047 & 360.000 & 273.945 & 76,10 \\
\hline 2018 & 82.706 & 80.982 & 360.000 & 163.688 & 45,47 \\
\hline Total & 827.020 & 842.491 & & 1.669 .511 & \\
\hline
\end{tabular}

(Sumber Data: UPTD. Trans Sarbagita, 2019)

Bus Trans Sarbagita Koridor I (Kota-GWK) merupakan trayek angkutan umum yang melewati wilayah perkotaan di mana banyak aktivitas masyarakat khususnya Kota Denpasar dan Kabupaten Badung beraktivitas seperti bekerja, sekolah maupun kuliah. Namun masih terdapat masalah yang terjadi seperti ketepatan waktu kedatangan bus (headway) yang masih sangat kurang (Widhyastuti, Pascarani, \& Yudharta, 2016). Lebih lanjut diungkapkan hasil penelitian (Wulandari, NPC., dan Sudiana, 2018) bahwa aksesibilitas Bus Trans Sarbagita dari segi ketepatan waktu sangat tidak efektif.

Pelayanan Bus Trans Sarbagita Koridor I (Kota-GWK) berawal dari Undang Undang 22 Tahun 2009 mengenai Lalu Lintas dan Angkutan Jalan, dibentuklah sebuah Peraturan Presiden Nomor 45 Tahun 2011 tentang Perencanaan Tata Ruang di Sarbagita. (Timney, 2007) pemerintah daerah lebih memiliki kemampuan dan keahlian dalam menemukan kebutuhan yang lebih spesifik untuk memecahkan permasalahan transportasi pada tingkat pemerintah daerah, kebijakan transportasi menurut Timney, sangat tepat dan strategis jika dibangun pada tataran lokal. (Mulyadi, 2016) mengemukanan bahwa implementasi bersifat mengarahkan suatu kebijakan ke wujud yang nyata.

Berdasarkan tulisan yang dipublikasikan dari (Brendon, 2004) transportasi publik merupakan tempat yang diperuntukkan masyarakat untuk melakukan mobilisasi agar kemacetan dapat berkurang, sehingga perjalanan lebih cepat dan mudah. (Diana, 2010), menggunakan sektor publik memberikan manfaat yang penting terhadap kehidupan manusia dan kualitas hidup. Dengan menggunakan sektor publik lebih terjamin akan ketertiban, perencanaan tata ruang, dan pencegahan dan pengendalian bencana.

Secara umum transportasi publik yang ada di daerah perkotaan adalah ojek, taksi, angkutan kota dan angkutan massal (bus, kereta api maupun waterways). Atas dasar inilah maka kebijakan-kebijakan yang disusun oleh pemerintah kota seharusnya memperhatikan semua moda transportasi publik yang ada dan mungkin dimanfaatkan 
oleh masyarakat kota (Sulistio \& Kagungan, 2012). Dalam pelaksanaannya kebijakan ini tertumpu pada Standar Pelayanan Minimal (SPM) yang dimiliki tersendiri. Keberadaan SPM ini juga diputuskan langsung oleh Gubernur Bali dan diatur dalam Peraturan Gubernur Bali Nomor 11 Tahun 2011 tentang Penetapan SPM Trans Sarbagita.

Menurut (Hensher, Mulley, \& Yahya, 2010), layanan kualitas transportasi publik adalah hal terpenting permintaan perjalanan bagi pengguna. Untuk itu pemerintah meluncurkan transportasi yang nyaman dan aman serta dapat dinikmati oleh setiap kalangan masyarakat. Dengan menggunakan transportasi publik selain dapat mengurangi kemacetan, juga dapat berperan penting dalam mengembangkan daerah perkotaan secara berkelanjutan untuk mengantarkan penumpang (Stathopoulos \& Marcucci, 2014).

\section{Metode Penelitian}

Dalam penelitian ini penulis menggunakan metode penelitian survey-kualitatif naturalistik. Teknik pengumpulan data yang berhubungan dengan penelitian ini dilakukan melalui Library Research (Penelitian Kepustakaan) dan Field Research (Penelitian Lapangan) dibantu dengan closed interview kepada 42 responden (penumpang); 5 key informan yang didukung melalui observasi-dokumentasi, sehingga data yang akan diperoleh adalah data kualitatif yang diolah dari data skunder.

\section{Hasil dan Pembahasan}

\section{Kualitas Pelayanan Angkutan Umum Trans Sarbagita Koridor I (Kota-GWK)}

Angkutan umum bus Trans Sarbagita Koridor I (Kota-GWK) memiliki kapasistas kursi sebanyak 35 orang. Dalam sehari hanya 4 (Empat) armada yang beroperasi, satu armada yang lainnya tetap berada di Pool sebagai cadangan apabila terjadi kerusakan pada salah satu armada yang beroperasi. Setiap armada bus dapat dua kali Pulang-Pergi dari Kota-GWK dalam satu hari. Sehingga apabila dihitung ada sekitar 250 orang dalam sehari yang menggunakan transportasi ini.

Pada koridor I (Kota-GWK) jumlah penggunanya lebih besar dibanding dengan koridor lainnya. Hal ini dikarenakan jalur yang dilewati oleh bus Trans Sarbagita Koridor I (Kota-GWK) ini melalui beberapa sekolah dan universitas, utamanya menyambungkan kampus Udayana yang berada di kawasan Bukit Jimbaran dengan kampus Udayana yang berada di Jalan Sudirman. Maka transportasi ini memang cenderung diminati oleh para mahasiswa khususnya mereka yang merantau atau tidak memiliki kendaraan pribadi.

Fasilitas yang tersedia dalam pelayanan angkutan umum Trans Sarbagita (ketampakan fisik) merupakan hal penting untuk diperhatikan agar bisa menarik hati masyarakat sebagai pengguna layanan. Bus Trans Sarbagita juga telah semaksimal mungkin memberikan pelayanan yang berkualitas kepada penumpang, baik penumpang prioritas maupun tidak. Meskipun masih ada masalah dalam pelayanan tersebut seperti pendingin udara yang kurang berfungsi dengan baik. 
Kemudian kurang mendukungnya fasilitas khusus bagi para penumpang yang berkebutuhan khusus, tempat halte yang tersedia kurang terawat. Selain itu penampilan petugas menjadi salah satu faktor penunjang pelayanan yang baik. Penampilan dari para petugas juga dapat dijadikan sebagai penilaian terhadap kesiapan dalam memberikan pelayanan kepada pengguna publik. Selain itu terdapat beberapa halte yang telah menggunakan seperti beban tangga untuk kaum difabel yang berbentuk miring, namun dikarenakan keterbatasan anggaran, tidak disemua tempat atau tidak disemua halte yang telah mendukung fasilitas khusus bagi kaum difabel tersebut.

Kemampuan (kehandalan) petugas dalam memberikan layanan dengan penyampaian informasi yang akurat dapat mendorong kepercayaan petugas serta tanggung jawab dari petugas dalam memberikan informasi yang dibutuhkan oleh penumpang bus Trans Sarbagita Koridor I (Kota-GWK). Namun demikian, masih ada kemampuan para petugas dalam memberikan informasi belum berjalan dengan baik. Seperti papan informasi (running text) sering mati (off), sehingga petugas memberikan informasi setiap halte (koridor) kepada layanan belum efektif dirasakan, penyejuk ruangan sering mati dan tidak ada pewangi ruangan.

Daya tanggap (ketanggapan) petugas pelayanan seperti memberikan respon kepada para penumpang ketika membutuhkan bantuan, menghadapi keluhan dari penumpang, serta kesigapan petugas dalam melihat lingkungan sekitar. Hasil penelitian menunjukkan faktor tersebut belum memuaskan karena petugas lambat merespon dengan baik. Daya tanggap sendiri berkaitan dengan ketanggapan para petugas yang nantinya akan meningkatkan kenyamanan pengguna layanan, yang kemudian menjadi salah satu pendorong keberhasilan pelayanan, karena daya tanggap pelaksanaan pelayanan akan mempengaruhi hasil kinerja sebab jika pelaksanaan pelayanan didasari oleh sikap, keinginan, dan komitmen untuk melaksanakan pelayanan yang bak, maka akan terjadi peningkatan kualitas pelayanan.

Aspek jaminan yang meliputi bagaimana perilaku pekerja maupun perusahaan untuk menumbuhkan kepercayaan da rasa aman terhadap pelanggan sehingga terbebas dari ancaman bahaya, resiko dan keragu-raguan. Jaminan yang dimaksud disini dapat berupa jaminan dari para petugas contohnya menjamin keselamatan para penumpang selama perjalanan dengan berbagai cara, misalnya dengan memberitahu jika kuota bus tersebut hanya menampung berapa orang, bagaimana aturan kecepatan yang ditempuh dan lainnya. Jaminan disini tidak hanya berupa jaminan keselamatan saja tetapi juga berupa jaminan atau kepastian waktu pengoperasian yang berupa waktu kedatangan hingga waktu keberangkatan angkutan umum bus Trans Sarbagita Koridor I (Kota-GWK). Sedangkan dari jaminan waktu operasionalnya masih dirasa kurang baik karena calon penumpang harus menunggu dalam waktu yang cukup lama.

Hasil wawancara para petugas bus Trans Sarbagita Koridor I (Kota-GWK) sudah menunjukkan sikap empatinya kepada semua pengguna layanan. Petugas 
juga dengan sigap membantu para penumpang yang dirasa membutuhkan bantuan, baik membutuhkan bantuan informasi maupun membutuhkan bantuan secara langsung seperti membantu menaikkan penumpang yang membawa anak. Dimensi ini dirasakan sudah dilaksanakan dengan baik, hal tersebut dapat dilihat dari sikap empati yang ditunjukkan oleh para petugas terhadap para penumpang. Khususnya kepada para penumpang prioritas seperti ibu membawa anak dan lansia. Meskipun untuk saat ini belum ada regulasi atau kebijakan yang mengatur tentang pelayanan khusus untuk kaum difabel.

\section{Faktor Penghambat Kualitas Pelayanan Angkutan Trans Sarbagita Koridor I (Kota-GWK)}

Latar belakang yang mendasari kemunculan program transportasi publik terintegrasi pertama di Bali ini adanya permasalahan tingginya kemacetan di kawasan Sarbagita utamanya di Kota Denpasar dan Kabupaten Badung. Upaya mengatasi persoalan kemacetan ditempuh pemerintah dengan pelbagai upaya seperti membangun jalan tol di atas laut, membangun underpass di kawasan Simpang Dewa Ruci serta meluncurkan program transportasi Bus Trans Sarbagita. Langkah-langkah yang ditempuh Pemerintah Provinsi Bali untuk mengatasi kemacetan dengan membangun ruas jalan tol, underpass, dan mengembangkan layanan transportasi umum berkaitan dengan pendapat (Farkas, 2007), (Sakamoto, 2011) dan (Wiyono, 2012). yang menyebutkan penataan serta pengoperasian moda angkutan umum akan mampu mengatasi persoalan kemacetan, namun tidak demikian halnya dengan pembangunan jalan baru, Farkas dan Sakamoto menjelaskan bahwa menambah ruas jalan atau menambah konstruksi jalan tidak akan serta merta membebaskan kawasan metropolitan dari kemacetan parah.

Program Trans Sarbagita memilki waktu keberangkatan setiap 1 jam sekali dari posko keberangkatan, hal ini berdampak pada rasio-efektif pelayanan transportasi publik yang berjalan maksimal setiap 10-15 menit sekali berdasarkan menuju lalu lintas dan angkutan jalan yang tertib (Kusumawardani, Adawiyah, Riyanto, \& Insriastuti, 2013). Waktu yang digunakan oleh kendaraan untuk melewati suatu rute tertentu atau lama perjalanan ke dan dari tempat tujuan setiap harinya, termaksud waktu berhenti untuk menaikkan dan menurunkan penumpang dan perlambatan karena hambatan di jalan. Parameter yang menentukan kualitas pelayanan angkut umum mengacu pada pedoman Teknis Penyelenggaraan Angkutan Penumpang Umum di Wilayah Perkotaan Dalam Trayek Tetap dan Teratur, Direktur Jenderal Perhubungan Darat, Departemen Perhubungan tahun 2002.

Hasil penelitian menunjukkan masih adanya keterlambatan bus Trans Sarbagita disebabkan saat ini hanya memiliki 3 (Tiga) unit bus dengan 23 (Tiga Puluh Tiga) rute di Denpasar. Di mana rutenya hanya mencakup area dari Utara (Gianyar) dengan satu pemberhentian di Batubulan ke Selatan (Badung) dengan satu pemberhentian di GWK (Garuda Wisnu Kencana). Pemberhentian paling Barat 
di Ungasan 1 (Badung) dan pemberhentian paling Timur adalah Batubulan (Gianyar), sebagaimana terlihat dalam gambar berikut:

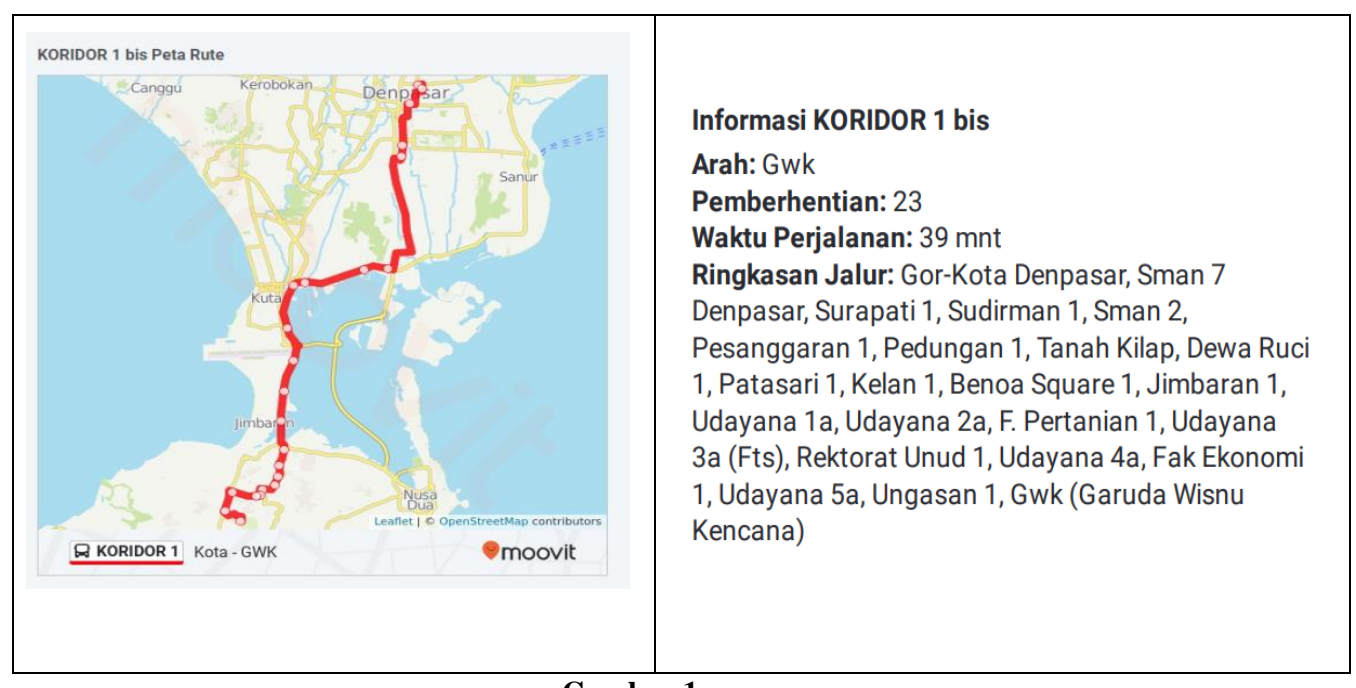

\section{Gambar 1}

Rute Trans- Sarbagita Koridor 1

Salah satu yang peneliti observasi terkait menurunnya kualitas pelayanan dilihat dari jumlah armada bus Trans Sarbagita yang disebabkan oleh menurunnya jumlah penumpang (load factor) yang tidak sesuai target ideal. Bahkan rendahnya load factor tersebut berdampak pada efisiensi biaya operasional kendaraan bus yang diawali penganggarannya sebesar 17 Milyar menjadi 4 Milyar di Tahun 2018. Tidak tertutup kemungkinan pengurangan dana itu berdampak pada pergantian armada; Operasional bus besar berkapasitas 55 kursi sebanyak 90 unit tidak dioperasionalkan; Sebagai gantinya yaitu 3 unit bus medium kapasitas 35 penumpang berukuran medium ini digunakan melayani koridor I trayek Kota GWK.

Efisiensi biaya operasional tersebut berdampak pula pada durasi waktu tunggu bus, di samping jarak tempuh antara bus satu dengan bus berikutnya selama 1 (Satu) jam. Mengingat kualitas waktu untuk ukuran moda transportasi umum (public transportation) waktu tunggu satu jam tidak ideal. Bandingkan dengan waktu tunggu angkutan berbasis daring, waktu tunggu hanya hitungan beberapa menit, hal itu dilakukan dikarenakan ketersediaan anggaran yang ada.

Dampak keterlambatan lainnya menyebabkan masyarakat berpindah alternatif pilihan lainnya yakni kendaraan pribadi. Bagi warga Bali pilihan terakhir ini menjadi pilihan terbaik untuk memudahkan beraktifitas. Apalagi hampir setiap rumah di Bali memiliki minimal 2 unit motor. Dampak tersebut dikhawatirkan terjadi penutupan trayek Bus Sarbagita karena transportasi publik tersebut dinilai belum dibutuhkan masyarakat Bali. Namun diduga justru Trans-Sarbagita jadi sumber kemacetan, kalau di Jakarta dibuatkan jalur khusus (separtor-way) sehingga lebih efektif dan tentunya dikelola secara profesional. Hasil wawancara ditemukan 
bahwa kebutuhan sarana transportasi bus tersebut belum menumbuhkan daya tarik untuk penggunaannya, hal ini menyebabkan pengelolaannya tidak efektif. Disamping itu kondisi geografis Bali memang tidak dirancang sebagai kota besar, sehingga perlu ada kajian mendalam untuk transportasi publik yang tepat bagi masyarakat Bali, karena secara existing daya dukung wilayahnya terbatas, namun supply-demand kendaraan begitu tinggi, sehingga beberapa kita lihat traffic jam di beberapa lokasi yang membuat busway trans-sarbagita tidak memungkinkan menggunakan jalan sempit.

Secara garis besar, lambannya perkembangan program Bus Trans-Sarbagita disebabkan oleh 3 (tiga) hal utama, yakni belum diprioritaskannya program, keterbatasan anggaran, budaya masyarakat yang sudah terbiasa bepergian menggunakan kendaraan pribadi. Selain itu masalahnya berpangkal dari ketiadaan dana untuk belanja modal serta investasi pembukaan koridor baru secara mandiri. Alokasi anggaran program Trans Sarbagita yang selama ini dikucurkan hanya difokuskan untuk biaya operasional program, dan tidak untuk pembukaan koridor baru yang selama ini skema pembukaan koridor baru selalu bergantung terhadap bantuan bus dari pemerintah pusat, sehingga kejelasan waktu pembukaan koridor baru belum direalisasikan.

Selain ke-3 faktor tersebut, beberapa faktor penghambat lainnya masih adanya prasarana yang belum memadai, serta ketergantungan yang teramat besar terhadap bantuan pemerintah pusat turut berperan dalam kelambanan perkembangan program. Hal ini sejalan dengan pendapat (Setyawati, 2012); (Putra \& Angga, 2016) yang mengatakan bahwa permasalahan program transportasi di suatu kota tidak terlepas dari permasalahan sosial-politik dan budaya yang sangat kompleks saling berkaitan.

Begitupula hasil penelitian ini menunjukkan bahwa bus Trans-Sarbagita belum memenuhi persyaratan dan tuntutan masyarakat Bali tentang transportasi umum yang baik karena ditunjukkan oleh perilaku dan budaya masyarakat yang belum menjadikan transportasi publik sebagai andalan ketika bepergian, sehingga tingkat load-factor-feeder menjadi belum optimal yang memberikan pengaruh terhadap rendahnya hasil pendapatan operasional bus Trans Sarbagita Koridor I (Kota-GWK); ditambah keberadaan jalan layang di Kota Bali belum dapat menerima keberadaannya. Akibatnya, jalan harus dibangun di permukaan tanah pada lahan yang sangat-terbatas dan sempit.

\section{Kesimpulan}

Mengacu pada kuesioner yang telah digunakan dalam penelitian, masih ada tanggapan informan yang menunjukkan sikap kurang baik atau ketidakpuasan terhadap kehandalan dari pegawai Bus Trans Sarbagita yang disebabkan sarana dan prasarana tidak optimal, hal ini dilihat dari:

a. Aspek ketampakan fisik berupa halte bus yang tidak terawat, banyak sampah, papan informasi sering mati (offline), tidak ada khusus difabel dan aksi vandalism. 
b. Aspek kemampuan petugas pemberi layanan informasi belum berjalan efektif dikarenakan adanya pengurangan jumlah armada bus.

c. Aspek daya tanggap petugas untuk menyelesaikan keluhan sangat lama, sikap responsif masih rendah, kesigapan belum maksimal.

d. Aspek jaminan ditunjukkan oleh jam operasional bus Trans Sarbagita tidak sesuai dengan jadwal, sering mengalami keterlambatan di koridor I, armada bus terbatas, dan petugas tidak dapat memberikan jaminan tepat waktu dalam pelayanan.

Hadirnya program Trans Sarbagita diharapkan dapat meningkatkan kepuasan pelayanan publik, namun demikian keberadaannya belum mencerminkan pelayanan yang berkualitas sebaagai bentuk kinerja pemerintahan, di samping perilaku dan budaya masyarakat juga belum menjadikan transportasi publik sebagai pilihan alternatif moda transportasi. Sebagai upaya untuk pengembangan program layanan angkutan umum berkualitas khususnya Trans-Sarbagita Koridor I (Kota-GWK) perlu adanya rekomendasi sebagai berikut:

1. Perkembangan Program Bus Trans-Sarbagita disarankan untuk segera dilakukan upaya revitalisasi rute atau trayek jalur angkutan yang tidak saja dilalui jalur sekolah dan tempat kerja, tetapi akan lebih baik dan bernilai investasi sangat besar apabila melalui rute wisata, sehingga keberlanjutan secara finasial-economy pun dapat terpenuhi karena pendapatan dan pengeluaran minimal seimbang.

2. Peningkatan kualitas pelayanan Bus Trans-Sarbagita disarankan meningkatkan konektivitas antarmoda transportasi publik, sehingga akesesibilitas terhadap haltehalte mudah digunakan oleh masyarakat dan mempercantik halte dengan standarisasi pelayanan publik baik dari aspek sapras, jalan trotoar maupun kebersihannya.

3. Agar dapat menarik animo masyarakat Bali terhadap keberadaan moda Trans Sarbagita Koridor I disarankan diadakannya promosi kepada masyarakat melalui beberapa inovasi yang sangat menarik. (dapat dilakukan kajian komparatif dengan pengelolaan Trans Jakarta). Inovasi-inovasi untuk promosi ini penting dilakukan agar masyarakat semakin tertarik mencoba layanan Trans Sarbagita. Tentu saja hal ini harus diimbangi dengan pengembangan koridor daru, rute wisata, dan peningkatan kualitas layanan (tepat waktu) agar masyarakat menaruh kepercayaan terhadap Trans Sarbagita 


\section{BIBLIOGRAFI}

Brendon, H. (2004). Trends Affecting Public Transit Effectiveness. A study prepared for the American Public Transportation Association.

Diana, M. A. (2010). Efficiency, Effectiveness And Perfomance of The Public Sector. Journal of Rumanian Journal of Economic Forecasting, 4.

Farkas, Z. A. (2007). 12 Urban Transportation Policy: The Baltimore Experience. Handbook of Transportation Policy and Administration, 207.

Hensher, D. A., Mulley, C., \& Yahya, N. (2010). Passenger experience with qualityenhanced bus service: the tyne and wear 'superoute'services. Transportation, 37(2), 239-256.

Kusumawardani, M. A., Adawiyah, R., Riyanto, B., \& Insriastuti, A. K. (2013). Evaluasi Efektivitas dan Efisiensi Angkutan Umum di Kawasan Tembalang. Jurnal Karya Teknik Sipil, 2(1), 60-74.

Mulyadi, D. (2016). Studi Kebijakan Publik dan Pelayanan Publik: Konsep dan Aplikasi Proses Kebijakan Publik Berbasis Analisis Bukti Untuk Pelayanan Publik.

Putra, I. G. A. B. A., \& Angga, G. A. B. (2016). Studi Evaluasi Program Bus Trans Sarbagita Pemerintah Provinsi Bali. Kebijakan Dan Manajemen Publik, 4(1), 1-9.

Sakamoto, K. dan S. B. (2011). Financing Sustainable Urban Transport. GTZ Sourcebook Module, Sustainable Urban Transport Project (www.sutp.org) Asia and the German Technical Cooperation.

Setyawati, A. (2012). Evaluasi Program Transjakarta dalam Upaya Perbaikan Transportasi Publik di Jakarta. Depok.

Stathopoulos, A., \& Marcucci, E. (2014). De gustibus disputandum est: Non-linearity in public transportation service quality evaluation. International Journal of Sustainable Transportation, 8(1), 47-68.

Sulistio, E. B., \& Kagungan, D. (2012). Studi Formulasi Kebijakan Penataan Sistem Transportasi Perkotaan Di Kota Bandarlampung .

Timney, M. M. (2007). 19 Transportation and Energy: Policy Dilemmas for the Twenty-First Century. Handbook of Transportation Policy and Administration, 359.

Widhyastuti, A. A. M., Pascarani, N. N. D., \& Yudharta, I. P. D. (2016). Implementasi Program Trans Sarbagita Dalam Pengembangan Transportasi Publik di Bali. Citizen Charter, 1(1). 
Wiyono, S. (2012). Penggunakan Sistem Dinamik Dalam Manajemen Transportasi Untuk Mengatasi Kemacetan Di Daerah Perkotaan. Jurnal Transportasi, 12(1).

Wulandari, NPC., dan Sudiana, I. (2018). Analisis Tingkat Efektivitas Trans Sarbagita Sebagai Transportasi Publik di Provinsi Bali. Jurnal Ekonomi Pembangunan, 7 No. 11 . 